\title{
Genotypic Influence on the Absorption, Use and Toxicity of Manganese by Soybean
}

\author{
Andre Rodrigues dos Reis ${ }^{1}$ and Jose Lavres Junior ${ }^{2}$ \\ ${ }_{1}^{1}$ Department of Civil and Environmental Engineering, Waseda University. 169-8555, \\ Shinjuku-ku, Okubo 3-4-1, Tokyo \\ ${ }_{2}^{2}$ Laboratory of Plant Nutrition, University of Sao Paulo. C.P.96 - 13400-970 - Piracicaba, SP \\ 1.topan \\ ${ }^{2}$ Brazil
}

\section{Introduction}

Plant species and genotypes within species can differ widely in their tolerance to excess manganese (Mn) (Foy et al., 1988) or susceptibility to its deficiency (Graham, 1988) in the soil or other substrate in which they grow. Often these differences are hereditary (Broadley \& White, 2005; Pittman, 2005). Although manganese (Mn) toxicity can be a common problem in tropical regions with acid soils, Mn deficiency in soybeans (Glycine max L.) grown in Brazilian Cerrado (savanna) has been recognized as a nutritional disorder frequently related to excessive liming (Tanaka et al., 1992). However, the variations in the concentrations of $\mathrm{Mn}$ in plants have been attributed either to genetic factors or to soil fertility conditions (Fageria, 2001). Plant species and genotypes within the same species can differ widely in the tolerance to high Mn (Foy et al., 1988) as well as in susceptibility to the deficiency when grown under conditions of low Mn availability (Graham, 1988).

The mechanisms of tolerance to excess Mn have been associated with oxidation of the Mn in the roots, restricted absorption by the roots and translocation of the excess $\mathrm{Mn}$ to the leaves, as well as uniform distribution in the tissues, greater internal tolerance and interaction with other elements (mainly $\mathrm{K}, \mathrm{Ca}, \mathrm{Mg}, \mathrm{Fe}$ and $\mathrm{Si}$ ) and defense mechanisms against oxygen reactive species, such as activation of enzymes like ascorbate peroxidase, catalase, Mnsuperoxide dismutase and glutathione peroxidase (Demirevska-Kepova et al., 2004; Morita et al., 2006). On the other hand, better internal utilization or lower requirement, greater redistribution of $\mathrm{Mn}$, increased rate of absorption, exudation of organic acids, acidification of the rhyzosphere and geometry of the root system have been reported as the main mechanisms responsible for lower susceptibility of Mn deficiency (Graham, 1988; Rengel, 1999).

The harmful effects of both deficient and excessive Mn on many species have been studied, mainly considering the morphological and anatomical aspects of the ultrastructure and biochemical aspects of the aerial part, where the symptoms are manifested, particularly the leaves (Demirevska-Kepova et al., 2004; Papadakis et al., 2007a,b). However, there are few reports on anatomical and changes in the root ultrastructure in response to variations in the supply of Mn (McQuattie \& Schier, 2000) and regarding the effect of genotype (Santandrea et al., 1998a,b; Izaguirre-Mayoral \& Sinclair, 2005). 
This work examines the anatomical changes of the leaf mesophyll and root cortex, and ultrastructural changes in root cells of three soybean cultivars, considering the nutritional disorders caused by deficient and excessive Mn in a nutrient solution.

\section{Material and methods}

The experiment was carried out in a greenhouse located at the Center for Nuclear Energy in Agriculture of the University of Sao Paulo, in Piracicaba, Sao Paulo State, Brazil. The three soybean cultivars - Santa Rosa (deficiency sensitive), IAC-15 (intermediate) and IACFoscarin 31 (toxicity tolerant) - of the species Glycine max (L.) Merrill were grown in a nutrient solution, from May 17 to June 27, 2006.

The seeds were germinated in a shallow tray containing vermiculite moistened with a calcium sulphate solution $\left(\mathrm{CaSO}_{4}, 10^{-4} \mathrm{~mol} \mathrm{~L}^{-1}\right)$. When the plants reached a height of $5 \mathrm{~cm}$ (phenology stage $\mathrm{V}_{1}$ ) they were transferred to individual pots (2.5 liter capacity and $15 \mathrm{~cm}$ diameter) containing $2.0 \mathrm{~L}$ of nutritive solution. The solution of Johnson et al. (1957), as adapted by Epstein \& Bloom (2005), was used, diluted to 1/5 the usual concentration, with initial $\mathrm{pH}$ of $4.97 \pm 0.03$. Three days after transplanting the seedlings, the nutrient solutions were added, at Mn concentrations of 0.5, 2.0 and $200.0 \mu \mathrm{mol} \mathrm{L}^{-1}$, with three repetitions.

The plants that showed the most visible symptoms of deficiency (grown in the solution with $0.5 \mu \mathrm{mol} \mathrm{L}-1$ of $\mathrm{Mn})$, toxicity $(200.0 \mu \mathrm{mol} \mathrm{L}-1)$ and the "healthiest" plants $(2.0 \mu \mathrm{mol} \mathrm{L}-1)-$ phenological states $V_{3}$ and $V_{4}$ - were chosen for tissue collection. For this purpose, the upper leaves and ends of the secondary roots that had absorbent hairs, around $10 \mathrm{~mm}$ from the root tip, were collected. Great care was taken to collect homogeneous material. The average diameters of the root cross-sections were obtained under an optical microscope and calculated using the Integrated System for Analysis of Roots and Soil Cover (Sistema Integrado para Análise de Raízes e Cobertura do Solo - SIARCS), version 3.0.

The leaf samples for electron transmission and optical microscopy were fixed in a modified Karnovsky solution. The sections were then examined under a Zeiss EM-900 transmission electron microscope at an accelerating voltage of $50 \mathrm{kv}$ and $3000 \mathrm{X}$ magnification. For optical microscopy, semi-fine sections $(150 \mathrm{~nm})$ were placed on glass slides and stained with $1 \%$ toluidine blue in a $1 \%$ borax solution. The slides were covered with slips using Entelan and observed under a Zeiss Axioscop $40 \mathrm{HBO} 50 \mathrm{~A} / \mathrm{C}$ optical microscope.

The plants were harvested at the time of sampling (reproductive cycle between $V_{3}$ and $V_{4}$ ) and later the upper leaves (blade and petiole) and roots were separated. The material, duly identified, was placed in paper sacks, dried in a forced-air oven at $65^{\circ} \mathrm{C}$ for 72 hours and weighed on a precision scale. The Mn concentration was determined by atomic absorption spectrometry, according to the method described by Malavolta et al. (1997).

The experimental setup was completely randomized blocks, with the treatments arranged in a $3 \times 3$ factorial scheme (three Mn doses $\times$ three soybean cultivars), with three replications. The data were submitted to statistical analyses by the SAS System for Windows 6.11 statistical program (SAS Inst., 1996). In cases where the F-test showed significant differences of means for the Mn doses, the Tukey test was applied to compare the means between the cultivars and doses $(\mathrm{P}<0.05)$.

\section{Results and discussion}

The Santa Rosa and IAC-15 genotypes showed visual symptoms of Mn deficiency 12 days after the start of the treatments, while the IAC-Foscarin 31 genotype showed them after 15 
days (Fig. 1). Only the Santa Rosa and IAC-15 cultivars showed visual signs of toxicity to excess $\mathrm{Mn}$ in the nutritive solution, six days after addition of the micronutrient in the solution $\left(200.0 \mu \mathrm{mol} \mathrm{L}^{-1}\right)$. There were no symptoms in the roots.
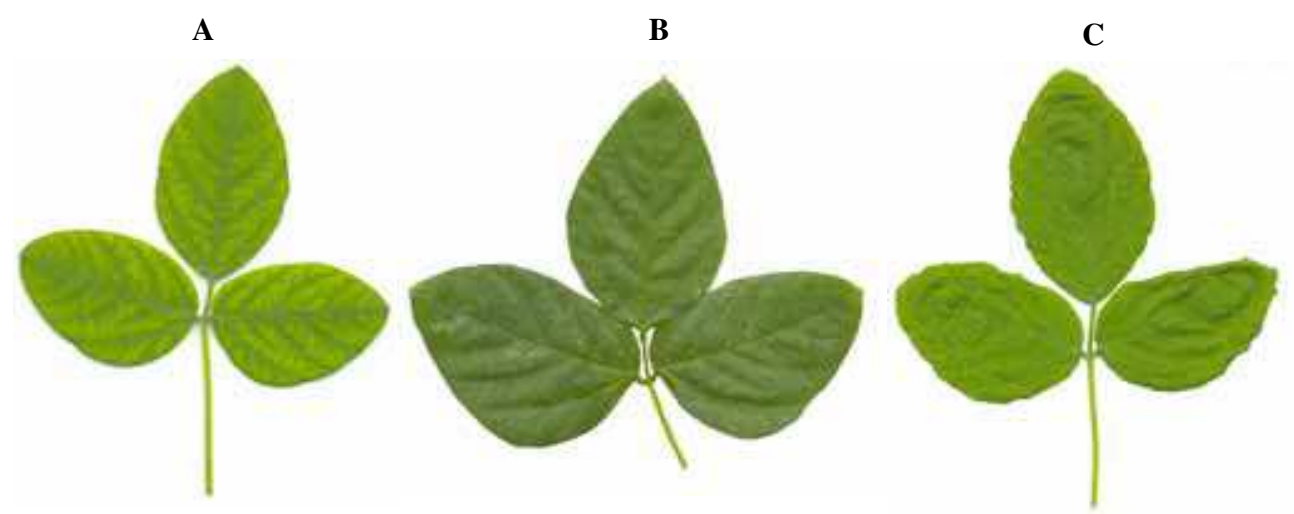

Fig. 1. Soybean leaf showing deficiency symptoms (A), Mn-normal leaf (B) and high-Mn concentration (C).

There also were no visual symptoms of Fe deficiency in the cultivars caused by excess $\mathrm{Mn}$ in the solution. The manganese concentrations in the leaf and root samples are shown in Table 1. Chlorosis of interveinal areas first appeared in younger leaves (Mn deficiency symptoms), whereas toxicity symptoms were observed both in the young (markedly) and old leaves. In all three genotypes, leaf $\mathrm{Mn}$ concentration increased as Mn concentration in the nutrient solution increased. In the $200 \mu \mathrm{mol} \mathrm{L}-1 \mathrm{Mn}$ treatment, higher Mn concentrations were found in leaves of IAC-15 followed by Santa Rosa and IAC-Foscarin 31 cultivars, respectively. However, there were no differences between the three cultivars with regard to leaf $\mathrm{Mn}$ concentration, for any of the three Mn treatments. In general, the critical deficiency range in fully expanded leaves is quite narrow, varying between 10 and $20 \mathrm{mg} \mathrm{kg}^{-1} \mathrm{dry}$ mass. On the other hand, critical leaf concentration for toxicity can vary within a very wide range, depending on plant species and genotypes within species, and on environmental conditions, such as temperature and mineral nutritional status (Fageria, 2001). Fageria (2001) attributed Mn concentrations in soybean leaves, respectively, of 67 and $720 \mathrm{mg} \mathrm{kg}^{-1}$, as adequate and toxic contents. Lima et al. (2004) pointed out concentrations of Mn of 1,800 mg kg-1 as being toxic to shoots of soybean cultivar Emgopa 316, grown in Oxissols from the Brazilian Cerrado.

The observations of the cross sections of the root tips allowed quantifying the average root diameter of the three cultivars (Table 2). The diameters of the IAC-15 cultivar increased by $63 \%$ and $116 \%$ with the increase of $\mathrm{Mn}$ in the solution from the lowest to the highest rate, respectively. This effect was not as evident for the other cultivars and did not translate into more efficient absorption of the $\mathrm{Mn}$, that is, a greater $V_{\max }$ value and lower $\mathrm{K}_{\mathrm{m}}$ and $\mathrm{C}_{\mathrm{mim}}$ values (Lavres Jr., 2007). The increased root diameter (root thickening) may have been caused by suberization and lignification of the cortex cells, thus reducing the absorption of water and nutrients (Fitter, 1996). 


\begin{tabular}{|c|c|c|c|}
\hline \multirow{2}{*}{ Mn rate $(\mu \mathrm{mol} \mathrm{L}-1)$} & \multicolumn{3}{|c|}{ Cultivars } \\
\hline & Santa Rosa & IAC-15 & IAC-Foscarin 31 \\
\hline & & Leaves --. & \\
\hline 0.5 & $12.5 \mathrm{cA}$ & $8.6 \mathrm{cA}$ & $9.8 \mathrm{cA}$ \\
\hline 2.0 & $30.6 \mathrm{bA}$ & $25.9 \mathrm{bA}$ & $24.0 \mathrm{bA}$ \\
\hline 200.0 & $786.3 \mathrm{aA}$ & $886.3 \mathrm{aA}$ & $744.3 \mathrm{aA}$ \\
\hline & & - Roots -- & \\
\hline 0.5 & $6.3 \mathrm{bB}$ & $11.0 \mathrm{cA}$ & $12.6 \mathrm{cA}$ \\
\hline 2.0 & $10.4 \mathrm{bB}$ & $16.3 \mathrm{bAB}$ & $20.3 \mathrm{bA}$ \\
\hline 200.0 & $379.4 \mathrm{aB}$ & $579.8 \mathrm{aA}$ & $546.1 \mathrm{aA}$ \\
\hline
\end{tabular}

Lower case letters on the same column and upper case letters on the same row do not differ significantly by Tukey test $(P<0.05)$.

Table 1. Mn concentration ( $\left.\mathrm{mg} \mathrm{kg}^{-1}\right)$ in the deficient leaf (Mn rate of $0.5 \mu \mathrm{mol} \mathrm{L-1}$ ), "healthiest" leaf (Mn rate of $2.0 \mu \mathrm{mol} \mathrm{L}^{-1}$ ) and high Mn leaf (Mn rate of $200.0 \mu \mathrm{mol} \mathrm{L}^{-1}$ ) and in the root of three-soybean cultivars: Santa Rosa, IAC-15 and IAC-Foscarin 31, as related to Mn rates of $0.5 ; 2.0$ and $200.0 \mu \mathrm{mol} \mathrm{L}^{-1}$ in the nutrient solution.

\begin{tabular}{cccc}
\hline \multirow{2}{*}{ Mn rate $(\mu \mathrm{mol} \mathrm{L}-1)$} & Cultivars & IAC-Foscarin 31 \\
\hline & Santa Rosa & IAC-15 & 0.30 \\
2.5 & 0.30 & 0.32 & 0.32 \\
200.0 & 0.29 & 0.52 & 0.35 \\
\hline
\end{tabular}

Table 2. Average diameters of the root cross-sections ( $\mathrm{mm}$ ) of three-soybean cultivars: Santa Rosa Rosa, IAC-15 and IAC-Foscarin 31, as related to Mn rates of 0.5; 2.0 and $200.0 \mu \mathrm{mol} \mathrm{L}^{-1}$ in the nutrient solution

In the treatment with a Mn dose of $0.5 \mu \mathrm{mol} \mathrm{L-1}$, there was disorganization of the xylem vessels (metaxylem and protoxylem) in the Santa Rosa and IAC-15 cultivars, indicating incomplete differentiation of these veins and of the cells of the vascular cylinder (Fig. 2 IA and IIA), when compared with the IAC-Foscarin 31 cultivar (Fig. 2 IIIA) and the control treatment, $2.0 \mu \mathrm{mol} \mathrm{L}-1$ (Fig. 2 IB and IIB). This can be associated with the initial appearance of deficiency symptoms in the newer leaflets. In the Santa Rosa and IAC-15 genotypes, grown at the lowest $\mathrm{Mn}$ rate, the number of xylem vessels was greater than in the IACFoscarin 31. Apparently there was no change in the differentiation of the cells of the cortex, epidermis, exodermis and endodermis. However, the IAC-Foscarin 31 plants in the control treatment $\left(2.0 \mu \mathrm{mol} \mathrm{L}^{-1}\right)$ showed a higher number of xylem vessels, particularly in the metaxylem, than did the IAC- 15 and Santa Rosa cultivars.

At a Mn dose of $200.0 \mu \mathrm{mol} \mathrm{L}^{-1}$, there was disorganization of the xylem vessels, mainly in the Santa Rosa cultivar, along with a larger number of metaxylem elements. In the IACFoscarin 31 cultivar, only protoxylem elements were observed, well arranged transversally along the central cylinder - medulla (Fig. 2 IIIC). The IAC-15 cultivar showed the presence of both a metaxylem (three veins) and protoxylem (three bundles containing an average of four veins each). The organization and ordering of the conducting veins, as well as the integrity of the cortical cells, play a fundamental role in the nutrient absorption and transport processes. If on the one hand an organized arrangement of the conducting veins 
can allow more efficient absorption (Rosolem et al., 2005) in the presence of low Mn availability, on the other hand when there is excessive Mn in the substrate, the maintenance of the integrity of the cells of the epidermis, exodermis, endodermis and cortex can provide greater compartmentalization of the $\mathrm{Mn}$ in the roots, thus reducing its long-distance transport and diminishing the toxicity in the shoot (Lavres Jr. et al., 2009). In this context, the apoplast "compartment" or free space apparently acts as a significant mechanism for tolerance to excess of the micronutrient, notably in tolerant (hyperaccumulator) plants, as recently discussed by Lavres Jr. et al. (2009) and Führs et al. (2008).

(I)

(A)

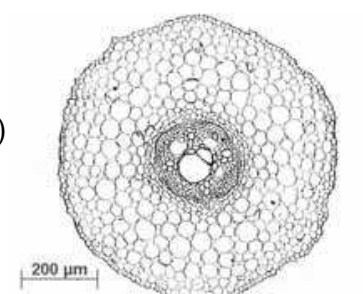

(B)

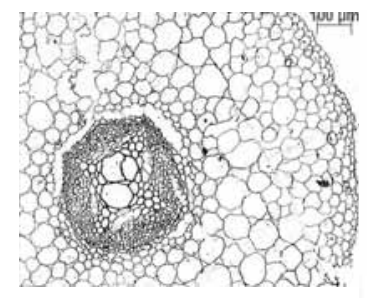

(C)

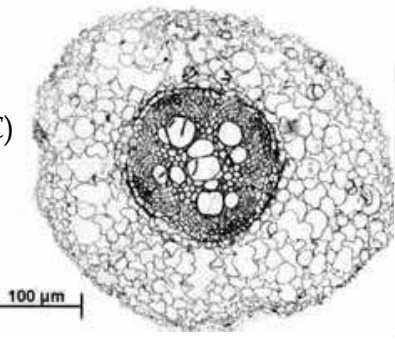

(II)
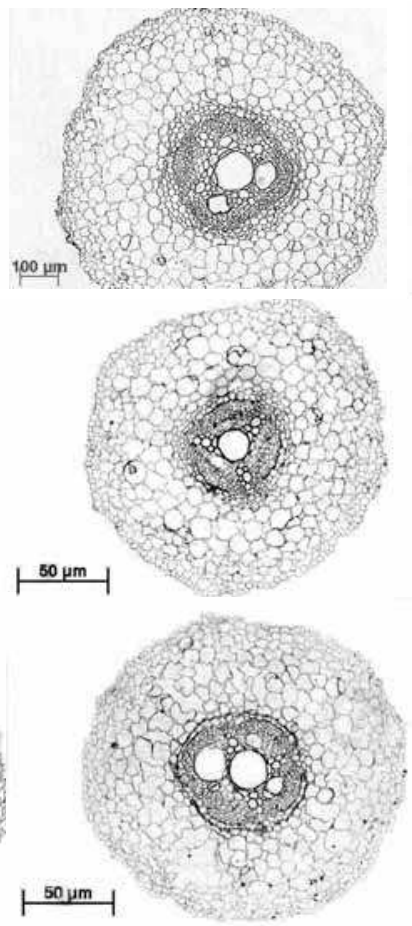

(III)

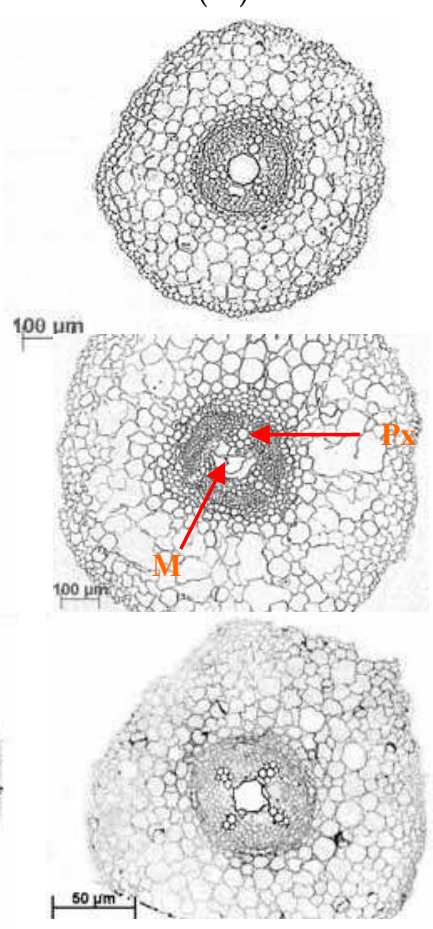

Fig. 2. Root cross-sections $10 \mathrm{~mm}$ from the root tip of three-soybean cultivars: Santa Rosa (I); IAC-15 (II) and IAC-Foscarin 31 (III), as related to Mn rates of $0.5 \mu \mathrm{mol} \mathrm{L}^{-1}$ (A), $2.0 \mu \mathrm{mol} \mathrm{L}^{-1}$ (B) and $200.0 \mu \mathrm{mol} \mathrm{L}^{-1}(\mathrm{C})$, in the nutrient solution. Anatomical features of the primary tissues: root cortex and bundle sheaths (xylem vessels). Xylem vessels detail (arrow) protoxylem (Px) and metaxylem (Mx)

However, Santandrea et al. (1998b) reported that plants tolerant to excessive Mn (5,000.0 $\mu \mathrm{mol} \mathrm{L}{ }^{-1}$ ) showed a greater number of xylem elements (protoxylem and metaxylem), with lignified walls, in relation to the control plants $\left(100.0 \mu \mathrm{mol} \mathrm{L}^{-1}\right)$. They also found that in the control group, the roots only showed protoxylem elements. With respect to lignification, it is known that $\mathrm{Mn}$, along with boron, $\mathrm{Cu}$ and $\mathrm{Fe}$, is involved in the metabolism of phenol compounds and the biosynthesis of lignin. Lignification occurs by the activation of 3-deoxy- 
D-arabino-heptulosonate-7-phosphate (DAHP) synthase [EC 2.5.1.54], in the secondary metabolism via shikimic acid. This phenomenon is more evident in the roots, which pose a physical barrier to the entrance of the pathogen. $\mathrm{Mn}$ is a co-factor for the lyase of phenylalanine and ammonia, producing cinnamic acid and other phenols, besides being a co-factor of peroxidases (Huber \& Graham, 1999; Malavolta, 2006; Morita et al., 2006; Thompson \& Huber, 2007).

The observations by electron transmission microscopy of the root cells of the three cultivars maintained in the solution with Mn concentration of $2.0 \mu \mathrm{mol} \mathrm{L}^{-1}$ (Fig. 3) revealed more normally shaped cell walls and middle lamella compared with those grown the lowest dose. The cells of the control treatment showed normally shaped nuclei and cytoplasm filled

(A)
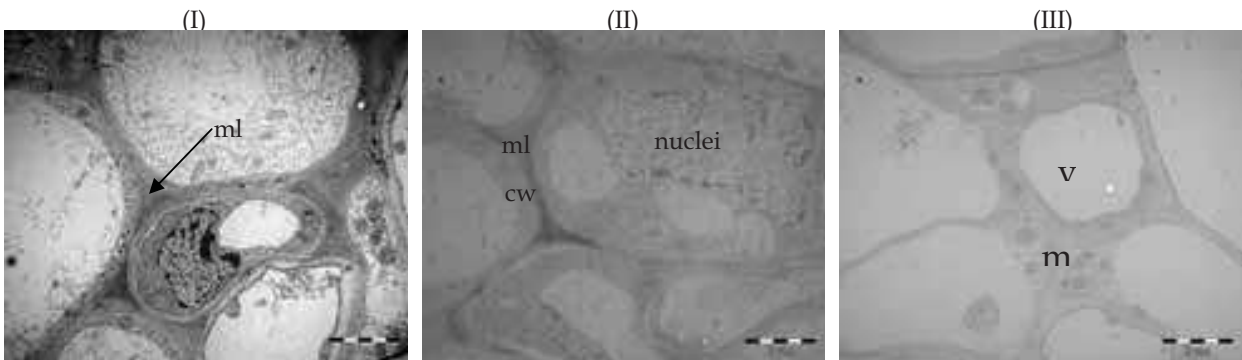

(B)
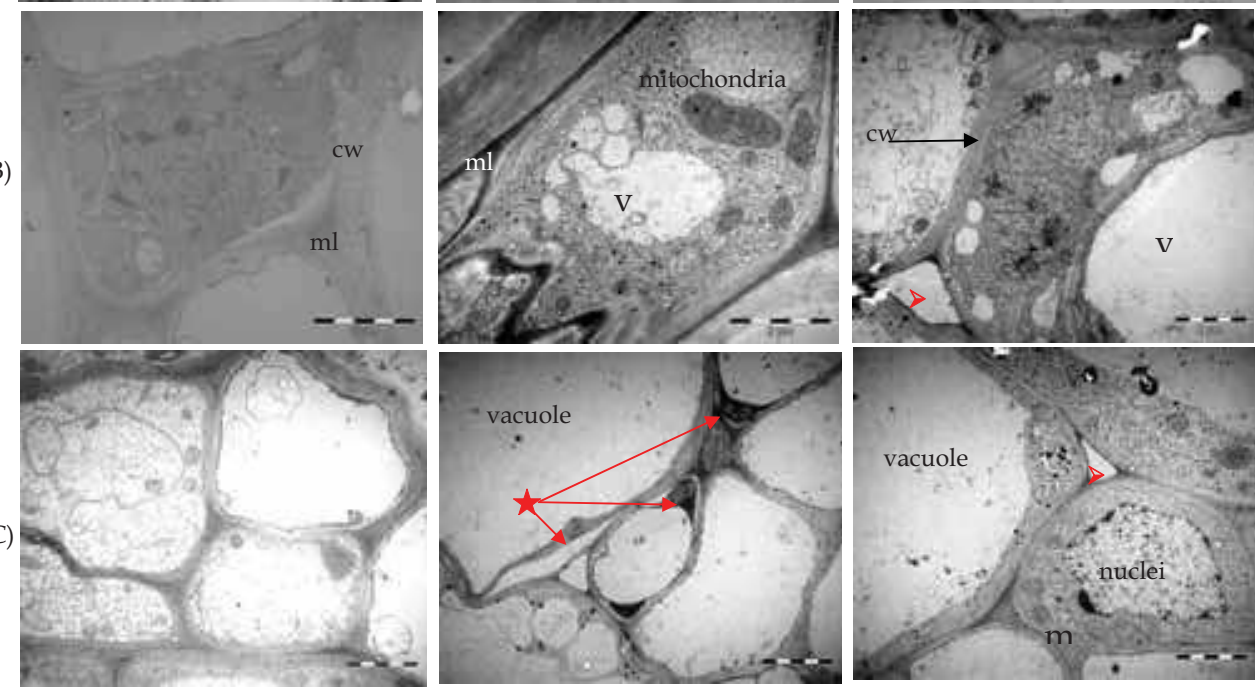

Fig. 3. Transmition electron micrographs $(x$ 3.000) showing root cell structures of soybean Santa Rosa (I), IAC-15 (II) and IAC-Foscarin 31 (III) cultivars, as related to Mn rates of 0.5 $\mu \mathrm{mol} \mathrm{L} \mathrm{L}^{-1}$ - deficiency (A), $2.0 \mu \mathrm{mol} \mathrm{L}-1$ - control (B) and $200.0 \mu \mathrm{mol} \mathrm{L}^{-1}$ - toxicity (C) in the nutrient solution. Abbreviations for all parts in alphabetical order: $\mathrm{c}$, chloroplasts; $\mathrm{cw}$, cell wall; ml, middle lamella; m, mitochondria; $n$, nuclei; v, vacuole. [ $\star$ ] Detail of separated protoplast from cell wall in the IAC-15 cultivar, under excess Mn in the solution, and the apoplast (or apparent free space) [ $>$ ] in the IAC-Foscarin 31, as related to $\mathrm{Mn}$ rates of 2.0 and $200.0 \mu \mathrm{mol} \mathrm{L}-1$. Scale bar: $2 \mu \mathrm{m}$ 
with organelles (mitochondria), besides few vacuoles. The most significant ultrastructural changes were found in IAC-15 supplied with $200.0 \mu \mathrm{mol} \mathrm{L}-1$ of $\mathrm{Mn}$. In this condition there was separation of the protoplasm from the root cell wall and an increase of vacuolated cells (Fig. 3 IIC). In IAC-Foscarin 31, both under normal supply and excess Mn in the solution (Fig. 3 IIIB and IIIC), there were inter-cellular spaces present, characterized as the apoplast (or apparent free space). This possibly contributes to greater accumulation and compartmentalization of $\mathrm{Mn}$ in the roots, thus reducing its long-distance transport and conferring greater tolerance to excess $\mathrm{Mn}$. This phenomenon is in agreement with the reports of Führs et al. (2008), who described that the leaf apoplast of the cowpea (Vigna unguiculata L.), a species also belonging to the Fabaceae family, is known for playing an important role in the tolerance to Mn excess/toxicity, because of the high activity of peroxidase in this compartment.

The optical microscopic observations allowed identification of structural differences in the mesophyll of the three cultivars (Fig. 4). At the lowest Mn rate the cross sections of the leaf blades of the Santa Rosa and IAC-Foscarin 31 cultivars had various mesophyll cell layers, making it hard to distinguish between the palisade and spongy parenchyma (Fig. 4 IA and

(I)

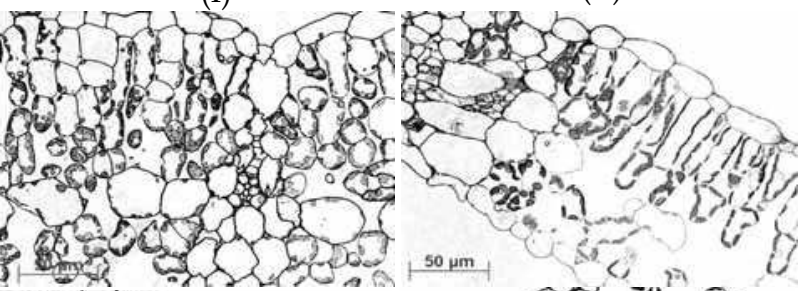

(A)

(B)

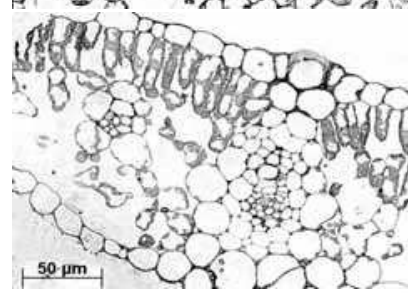

(C)

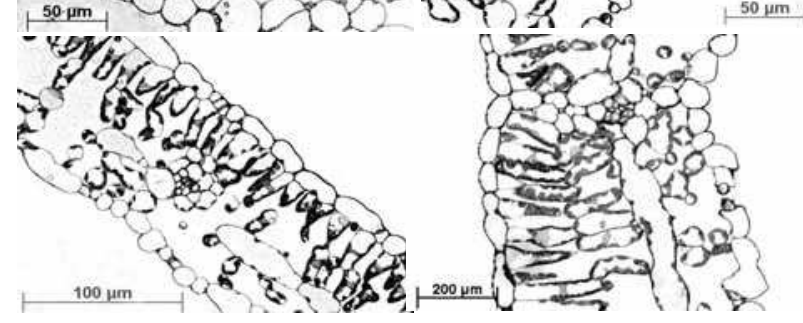

(III)
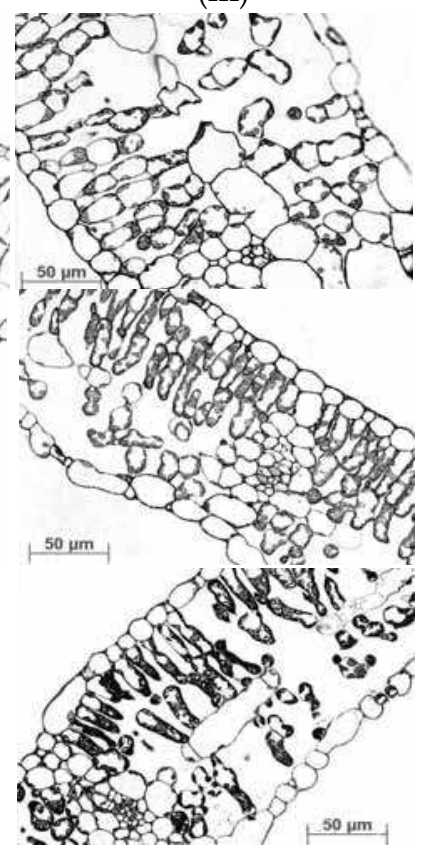

Fig. 4. Leaf blades cross-sections of three-soybean cultivars: Santa Rosa (I); IAC-15 (II) and IAC-Foscarin 31 (III), as related to Mn rates of $0.5 \mu \mathrm{mol} \mathrm{L}^{-1}(\mathrm{~A}), 2.0 \mu \mathrm{mol} \mathrm{L}^{-1}$ (B) and 200.0 $\mu \mathrm{mol} \mathrm{L}-1(C)$, in the nutrient solution. Anatomical features of the leaf tissues: mesophyll cell of the palisade parenchyma (two cell layers in the upper adaxial face - as related to Mn rates of 2.0 and $200.0 \mu \mathrm{mol} \mathrm{L}^{-1}$ ) and spongy parenchyma (a single layer of spongy cells in the abaxial face). 
IIIA). Both had broad and rounded cells, in agreement with the reports of Papadakis et al. $(2007 a, b)$. However, these layers were clearly distinct in the IAC-15 cultivar (Fig. 4 IIA). There was a reduction in the number of chloroplasts, particularly in the palisade tissue, when compared to the control treatment (Mn dose of $2.0 \mu \mathrm{mol} \mathrm{L}^{-1}$ ). This effect was stronger in the IAC-15 cultivar. Weiland et al. (1975) reported significant differences in the number of chloroplasts per cell of the palisade parenchyma of soybean plants, varying from six chloroplasts per cell under deficient conditions to nine in well supplied plants. The authors also noted this reduction in the cells of the spongy parenchyma. Papadakis et al. (2007a) also reported the negative effect of Mn deficiency in the reduction of the number of chloroplasts in citrus leaves. In another study, the primary effect of a lack of Mn in pecan leaves (Carya illinoinensis C. Koch.) was a reduction in the number of chloroplasts in mesophyll cells, but the Mn content of the chloroplasts remained the same as in those of the control treatment, without damage to photosystem II (Henriques, 2004). It should be pointed out, however, that the number of chloroplasts can vary according to the portion of the cell shown by cross sections. In other words, the possibility cannot be ruled out of obtaining a larger or smaller portion when making the histological slices.

The palisade and spongy parenchymas of the three soybean cultivars grown in the solution with Mn concentration of $2.0 \mu \mathrm{mol} \mathrm{L}^{-1}$ were distributed in orderly fashion in the mesophyll, enabling identification of two cell layers in the palisade parenchyma in the upper adaxial face of the blade and a single layer of spongy cells in the abaxial face. The mesophyll cells had normal sizes and shapes, with easily distinguishable chloroplasts distributed throughout the cells (Fig. 4).

At the highest Mn rate, the chloroplasts of the Santa Rosa and IAC-15 cultivars were concentrated in the lower part of the parenchyma cells (notably in the palisade tissue), resulting in a large area of cytoplasm and vacuole. The presence of a larger number of starch grains as well as the larger size of the plastoglobules in cultivar IAC-Foscarin 31, as reported by Lavres Jr. (2007), may have contributed to the smaller expansion of the vacuoles and cytoplasm, because of the increased size of the chloroplasts. Apparently there was no reduction in the number of chloroplasts in the three cultivars, unlike the finding of Santandrea et al. (1998a), who observed a smaller number of these organelles in the mesophyll cells of Nicotiana tabacum (L.) maintained in solutions with Mn of 2,000 and 5,000 $\mu \mathrm{mol} \mathrm{L}-1$, rates higher than those tested in the present study.

These results lead to the following question: Can the smaller extension of the vacuoles in the IAC-Foscarin 31 have an influence on the accumulation of the excess $\mathrm{Mn}$, or do the cells of the palisade parenchyma (greater number of chloroplasts) have the capacity to "store" the excess Mn? In a study of four forest species that are Mn hyperaccumulators - Gossia bidwillii, Virotia neurophylla, Macadamia integrifolia and Macadamia tetraphylla - Fernando et al. $(2006 a, b)$ suggested that the accumulation of the excess Mn in the leaves occurs by storage in the nutrient in the mesophyll cells of the palisade parenchyma (photosynthetically active tissue), as a behavior pattern in these accumulator plants, unlike what occurs with $\mathrm{Cu}$ and $\mathrm{Ni}$, which are accumulated in the tissues of the epidermis (trichomas) and in the vacuole (Arru et al., 2004; Broadhurst et al., 2004), and with Zn and Cd, which are accumulated in the vacuoles of the spongy mesophyll cells and apoplast (Küpper et al., 1999; Di Toppi et al., 2005). The accumulation of $\mathrm{Mn}$ in the form of oxalate crystals is debatable (González \& Lynch, 1999).

The scanning electron microscopy images of sections from Mn-deficient leaves, in all the three genotypes, showed a certain degree of tissue disorganization and minor alteration in 
the epidermis (abaxial and adaxial face), and no stomata reduction in relation of those observed in adequate Mn-supply $\left(2 \mu \mathrm{mol} \mathrm{L}^{-1}\right)$. At the highest Mn rate $\left(200.0 \mu \mathrm{mol} \mathrm{L}^{-1}\right)$, there were alterations in the epidermis and tissue agglomeration, resulting in epidermical hypertrophy - in other words, a huge disorganization in cell arrangement. This can also be confirmed by the morphometric assessments shown in Table 3. Under all Mn rates, there were no changes either in stomata length or stomata number both in the adaxial and abaxial face (Fig. 5), a finding that agrees with the observations of Weiland et al. (1975) and Baldisserotto et al. (2004). However, it should not be ignored that under severe Mn toxicity conditions, there was high disorganization of the tissue, characterized by hidden stomata throughout the leaf area as well. Nevertheless, Lidon (2002) observed, in rice plants grown in nutrient solutions containing 2.4, 145.0 and $582.0 \mu \mathrm{mol} \mathrm{L}^{-1}$ of $\mathrm{Mn}$, alteration in stomata length, which decreased by about $50 \%$ under the supply of the highest rate. He concluded that the reduction was associated with the physiological control of the rice plants, as the mechanism responsible for the low Mn transport from roots to shoots, i.e., as a consequence of low xylem flow, which might be altered by the variation of transpiration rates.

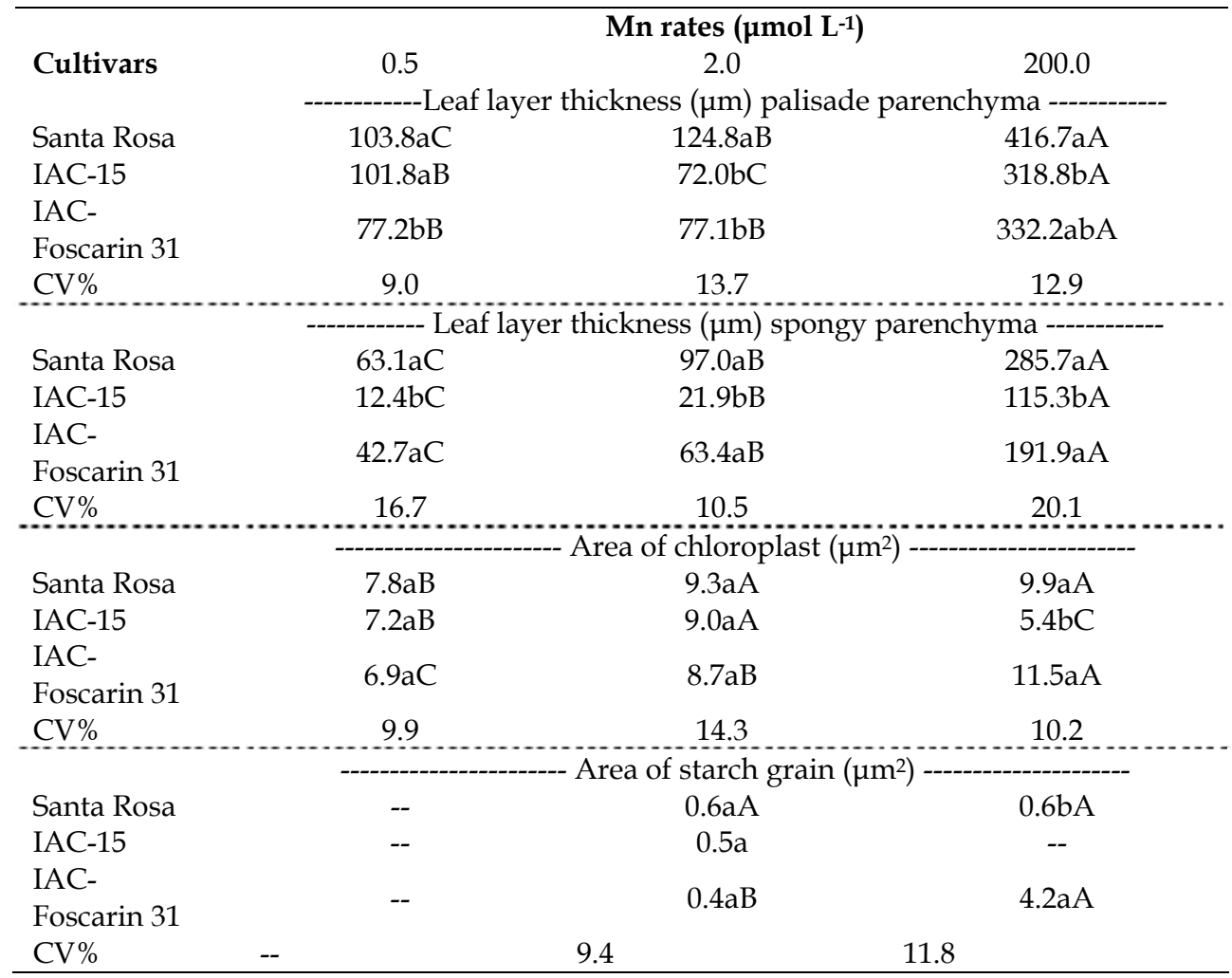

Lower case letters on the same column and upper case letters on the same row do not differ significantly by Tukey test $(p>0.05)$.

Table 3. Morphometric assessments of leaves (cross sections) and mesophyll chloroplasts of Santa Rosa, IAC-15 and IAC-Foscarin 31, as related to Mn rates in the nutrient solution. 
(I)

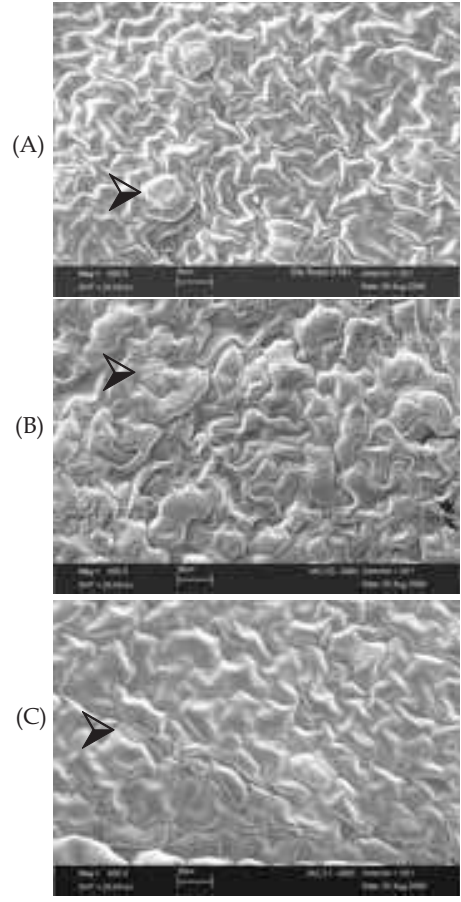

(II)

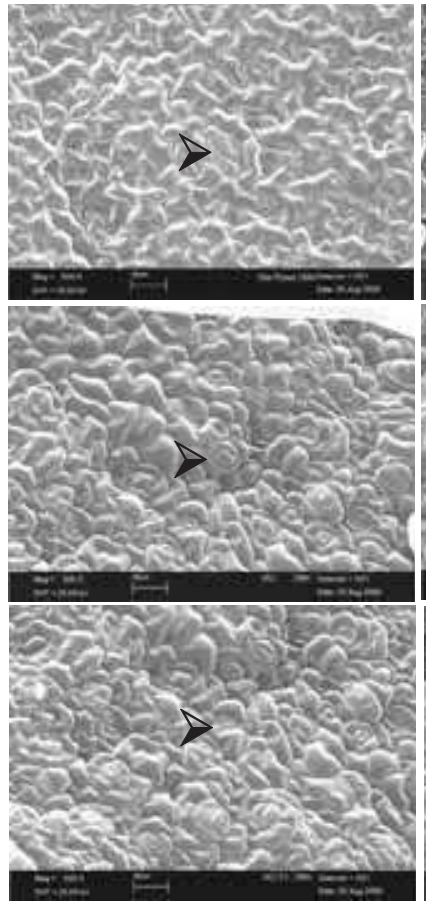

(III)

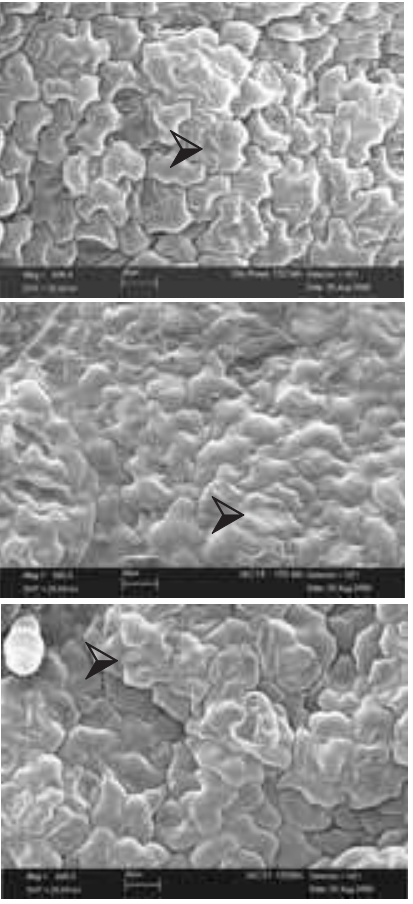

Fig. 5. Scanning electron micrographs showing stomata leaf of soybean Santa Rosa (I), IAC15 (II) and IAC-Foscarin 31 (III) cultivars, as related to Mn rates of 0.5 (A), 2.0 (B) and 200.0 $\mu \mathrm{mol} \mathrm{L}-1(\mathrm{C})$ in the nutrient solution. ( $\varangle$ ) Detail of the stomata. The scale of each picture has a value of $20 \mu \mathrm{m}$.

The external manifestation of abnormality caused by toxicity to any element, essential or not, is the result of a chain of occurrences that starts with an alteration at the molecular level, continues with sub-cellular modification, which in turn leads to a cellular change that finally causes disorganization of the tissue - the symptom. The deficiency of any nutrient also can trigger a series of events leading to the visual symptom. According to the anatomical changes and timing of manifestation of the symptoms of Mn deficiency and toxicity observed in this study, we can assume there are various mechanisms that act together to maintain the biochemical processes and structural apparatuses of plants, resulting in different degrees of tissue organization. We can also suggest that Mn detoxification of cells by activation of the antioxidant defense system (enzymatic or not), binding of Mn to complexing agents in the root system (phytochelatins, metallothioneins and nicotianamine) and subsequent deposit of $\mathrm{Mn}$ in the apoplast, reduction in long-distance transport of the metal-ligand complex, and finally, storage inside the vacuoles (Bidwell et al., 2002; Ducic \& Polle, 2005; Yan et al., 2000), can all be more effective in the tolerant genotype, IAC-Foscarin 31.

The deficiency of any nutrient can unleash this series of events until the appearance of a visible symptom. Several studies, more specifically dealing with the deficiency of $\mathrm{Mn}$ in plants, have demonstrated the role of $\mathrm{Mn}$ in the maintenance of chloroplast ultrastructures (Weiland et al., 1975), since Mn deficiency resulted in a reduction in the rate of PS II electron 
transport (Papadakis et al., 2007a,b,c). On the other hand, marked alterations in the Golgi apparatus and the endoplasmatic reticulum were observed (Izaguirre-Mayoral \& Sinclair, 2005), as well as in the mitochondria under Mn toxicity conditions (Santandrea et al., 1998). However, none of these effects were observed in the present study.

Transmission electron microscopy revealed ultrastructural alterations in the mesophyll of all the three genotypes (Fig. 6). Since the leaves were sampled when the first symptoms appeared (deficiency and toxicity), the anomalies did not progress to complete disorganization of the epidermis (abaxial and adaxial face). Furthermore, increased Mn concentration in the nutrient solution caused an increase in leaf lamina thickness, primarily due to increased length of palisade parenchyma cells (Table 3). The spongy parenchyma thickness also increased with higher rates of $\mathrm{Mn}$ in the nutrient solution, ranging from 63.1 to $285.7 \mu \mathrm{m}, 12.4$ to $115.3 \mu \mathrm{m}$ and 42.7 to $191.9 \mu \mathrm{m}$ for Santa Rosa, IAC-15 and IAC-Foscarin 31 , respectively.

(A)
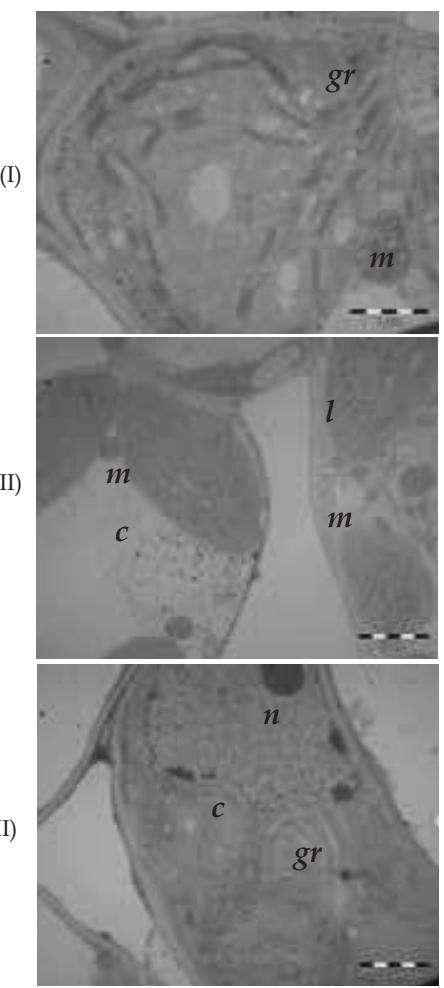

(B)
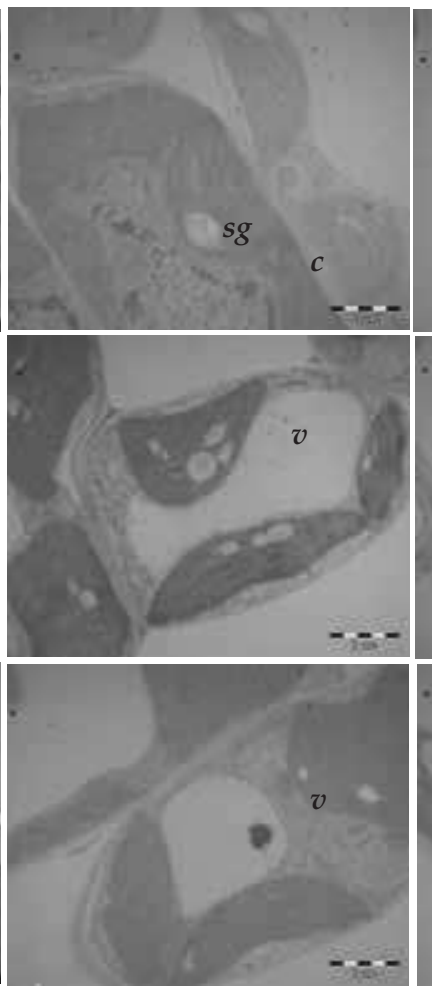

(C)

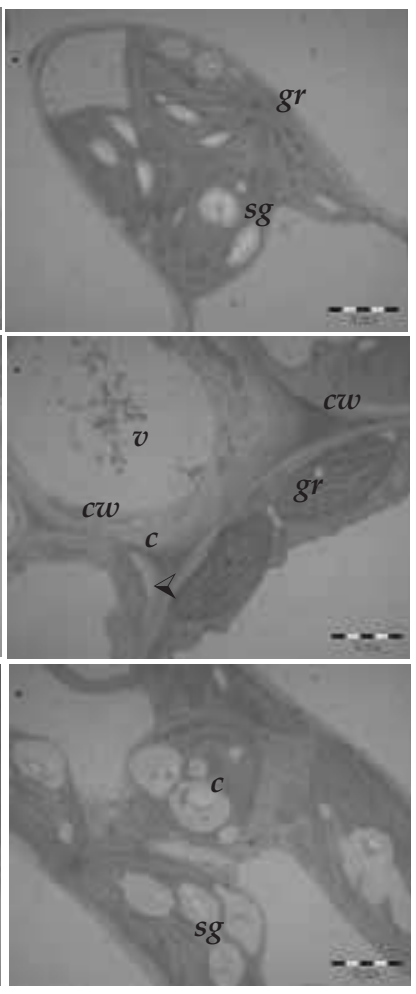

Fig. 6. Transmition electron micrographs showing leaf cell structures of soybean Santa Rosa (I), IAC-15 (II) and IAC-Foscarin 31 (III) cultivars, as related to Mn rates of 0.5 - deficiency (A), 2.0 - control (B) and $200.0 \mu \mathrm{mol} \mathrm{L-1}$ - toxicity (C) in the nutrient solution. Abbreviations for all parts in alphabetical order: c, chloroplasts; cw, cell wall; gr, grana; lp, lipid globules; $\mathrm{m}$, mitochondria; $\mathrm{n}$, nuclei; sg, starch grains; v, vacuole. ( $\varangle$ ) Detail of separated protoplast from cell wall. Scale bar: $1 \mathrm{~A}=1 \mu \mathrm{m}$ and other pictures $=2 \mu \mathrm{m}$. 
On the other hand, the palisade and spongy parenchymas of the three soybean cultivars grown in the solution with $2 \mu \mathrm{mol} \mathrm{L}-1 \mathrm{Mn}$ were regularly distributed. Two cell layers could be identified in the palisade parenchyma of the upper leaf surface and a single layer of spongy cells on the abaxial face. The mesophyll cells had normal size and shape, with easily distinguishable chloroplasts distributed throughout the cells. Most of these details can be observed in Lavres Jr. et al. (2010). These results are the same as pointed out by Papadakis et al. (2007c), who reported that increased Mn concentration in the nutrient solution caused an increase in leaf lamina thickness of orange plants, primarily due to increased length of palisade parenchyma cells. Furthermore, at a Mn rate of $686 \mu \mathrm{mol} \mathrm{L}^{-1}$, spongy parenchyma thickness also increased.

Transmission electron microscopy of transversely cut leaves from all genotypes grown at 0.5 $\mu \mathrm{mol} \mathrm{L}-1 \mathrm{Mn}$ revealed small chloroplasts with round aspect (markedly in Santa Rosa and IAC-Foscarin 31) and scarce starch granules. Stacked thylakoids (granum) around the stroma and a higher number of vesicles in the cytoplasm were also observed. However, extensive cytoplasmic disorganization, increased vacuolation and amorphous cytoplasm were more evident in IAC-15. In this case, alterations in the thylakoid membranes were evident (Fig. 6-IIA). For all genotypes, Mn-deficient chloroplasts were smaller than those of normal and Mn-toxicity (2.0 and $200.0 \mu \mathrm{mol} \mathrm{L}-1$ of $\mathrm{Mn}$, respectively) (Table 3), where chloroplasts occupied larger part of the cell volume. Within each chloroplast, the grana were arranged parallel to the envelope. Each granum was organized with two or three other grana into a stack characterized by a close association with adjacent granum surfaces. This effect was more evident in the Santa Rosa. Mn deficiency did not affect the ultrastructure of other cellular organelles, like the mitochondria and nucleus. The symptoms of $\mathrm{Mn}$ deficiency observed in soybeans in this study were similar to those described by Weiland et al. (1975).

On the other hand, chloroplasts at the highest Mn supply, especially with regard to the IAC15 leaves, had an elongated shape, with thylakoids piled in a disorderly manner, underdeveloped grana, scarce starch granules in comparison with those cultivars, and holelike folds in the thylakoid membrane. In short, there was a general disorganization within the chloroplast. An incomplete structure of the plastid was seldom observed. The cytoplasm had an amorphous and dense aspect (spotted), widely disorganized and with great number of vesicles. In a few cells the protoplast was separated from the wall towards the inner part of the cell (Fig. 3-IIC).

According to Santandrea et al. (1998), high levels of Mn damage the structure and function of cell membranes. Furthermore, separation of the cell membrane from the cell wall and rupture with formation of many cytoplasmatic vesicles in adjacent spaces can occur. Higher absorption of $\mathrm{Mn}$, as of other heavy metals, probably increases the formation of free radicals, causing thus peroxidative damage of the cell membranes (Morita et al., 2006).

The fact that lipid globules were observed in the IAC-15 chloroplasts - small electron-dense lipid globules usually situated along the stroma - at all Mn rates could indicate either alteration in the metabolic route of starch synthesis, or this could be a characteristic of the genotype. In contrast, the lipid globules were not evident in the IAC-Foscarin 31, irrespective of the Mn concentration in the nutrient solution. The role of $\mathrm{Mn}$ in the lipid synthesis process is not well known. However, the effect could be secondary, due to a low photosynthetic rate, which restricts the carbon supply for fatty acid synthesis. The reduction in the number of chloroplasts and the size of their inner membrane system as well as the 
amount of starch in Mn-deficient plants provides morphological evidence indicating a dysfunction of photosynthetic apparatus (Weiland et al., 1975; Henriques, 2003, 2004).

In the mesophyll cells of Santa Rosa and IAC-Foscarin 31 plants grown under Mn excess, the chloroplasts showed normal configuration with a well-organized inner membrane system. Usually there were three or four starch grains per chloroplast cross section (Fig. 6-IC and 6IIIC). As observed in IAC-Foscarin 31, there was an increase in the size of starch grains, which were swollen (Table 3). Doncheva et al. (2005) observed chloroplasts with distorted thylakoids, as well as increased size and number of starch grains, along with the presence of small vesicles and darkened stroma in pea plants (Pisum sativum L.) grown with a Mn rate of $3,000 \mu \mathrm{mol} \mathrm{L}-1$. They concluded that the most evident structural alteration in the chloroplasts was the increase in the number of starch grains, possibly due to inhibition of the transport of photosynthates from the leaf to other organs. Papadakis et al. (2007c) reported that Mn affected the size and shape of chloroplasts in seedlings of Citrus volkamericana (L.), which were shorter and thinner under $0 \mu \mathrm{mol} \mathrm{L}-1 \mathrm{Mn}$ compared to the treatments with 2 to 686 $\mu \mathrm{mol} \mathrm{L}{ }^{-1}$. Besides this, the percentage of starch grains per chloroplast was fivefold under 686 $\mu \mathrm{mol} \mathrm{L}-1$ in comparison with the treatments with 0 to $98 \mu \mathrm{mol} \mathrm{L}^{-1} \mathrm{Mn}$, as was also observed in IAC-Foscarin 31 in the present study.

\subsection{Kinetics of Mn uptake by soybean plants}

The cultivar IAC-Foscarin 31 absorbed a significantly higher amount of Mn compared to other cultivars, and this difference was increased from 10 hours of exposure time in $\mathrm{Mn}$ solutions. At the end of the evaluation period, it was found that the concentration of $\mathrm{Mn}$ in the exhaust solution of IAC-Foscarin 31 was $74.5 \%$. This value was $45.5 \%$ lower compared to cultivars Santa Rosa and IAC-15, respectively (Fig. 7(A)), which can be confirmed by the largest absolute growth rate of roots (Fig.7(A)). The largest absolute growth rate of roots was obtained by cultivars IAC-Foscarin 31 followed by IAC-15 and Santa Rosa from approximately 48 hours after start of exposure time in Mn solutions. It is known that in older plants, the inflow rate is smaller on basis of dry weight; because the number of absorption sites per unit mass is lower (Nye \& Tinker, 1977; Jungk, 1996; Reid, 1999).

Regarding to the influx of $\mathrm{Mn}$ in the roots, it was found the interaction between soybean cultivars and doses of $\mathrm{Mn}$ in solution, suggesting that there is a significant genotypic differences among the cultivars (Fig. 7(B)). Mean values of $\mathrm{V}_{\max }$ for IAC-Foscarin 31, IAC-15 and Santa Rosa were $0.67,0.50$ and $0.42 \mu \mathrm{mol} \mathrm{g}^{-1} \mathrm{~h}^{-1}$, whereas the respective $\mathrm{K}_{\mathrm{m}}$ values were $0.45,0.87$ and $1.02 \mu \mathrm{mol} \mathrm{L}-1$, respectively. The $\mathrm{K}_{\mathrm{m}}$ parameter for IAC-Foscarin 31 was $56 \%$ and $48 \%$ lower compared values presented by cultivars Santa Rosa and IAC-15, indicating a greater affinity for the charger of Mn by IAC-Foscarin 31. This physiological process is clearly showed in the Fig. 7(B), where the influx of Mn in low concentrations is higher.

\section{Conclusions}

In conclusion, the effects of Mn deficiency and toxicity on leaf cell ultrastructure, such as number, size and distribution of grana, starch grains and lipid globules per chloroplast, showed distinct differences among the three tested genotypes (IAC-15 and Santa Rosa were affected more).

According to the ultrastructural alterations as well as the periods of the appearance of visual symptoms of Mn deficiency and toxicity, the existence in Mn-tolerant IAC-Foscarin 31 of 


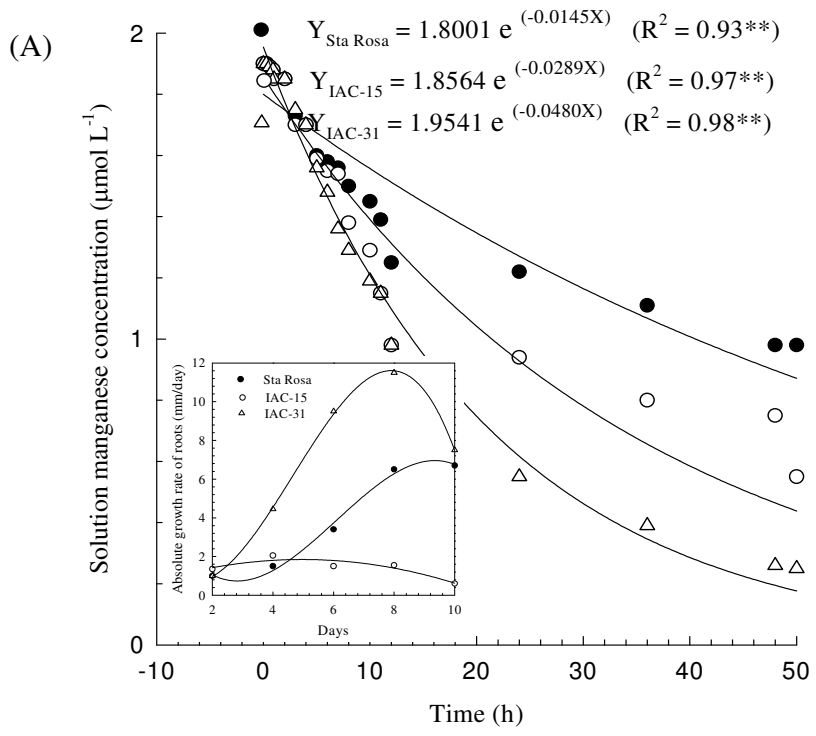

(B)

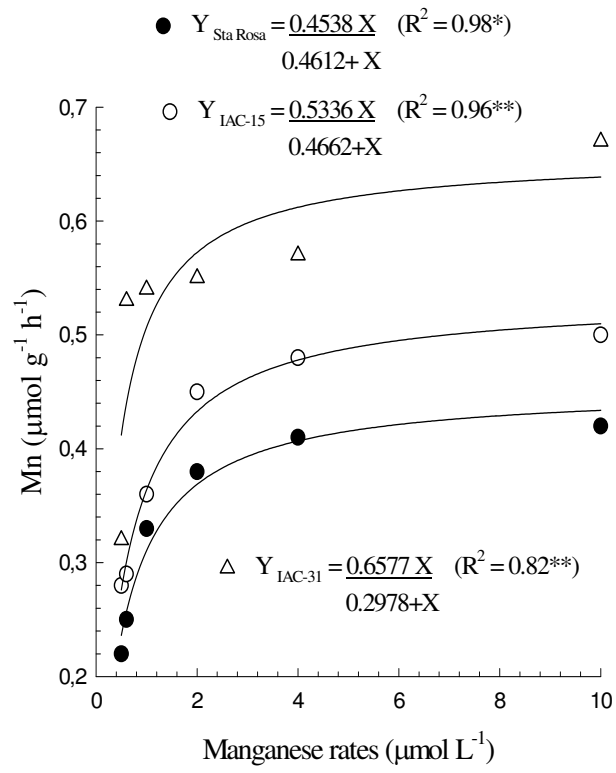

Fig. 7. (A) Time courses of manganese depletion of the external solution by intact soybean plant cultivars Santa Rosa $(\bullet)$, IAC-15 $(\bigcirc)$ and IAC-Foscarin $31(\triangle)$ (in the control treatment $(2 \mu \mathrm{mol} \mathrm{L}-1 \mathrm{Mn})$ of the long-term experiment; and absolute growth rate of roots as related to growth ages (days). (B) Manganese uptake rates during culture solution depletion for soybean cultivars Santa Rosa $(\bullet)$, IAC-15 $(\bigcirc)$ and IAC-Foscarin $31(\triangle)$ grown at different levels of Mn for 50 hours. 
several mechanisms that act jointly to maintain the structural and biochemical apparatus of the plants resulting can be supposed. This response of IAC-Foscarin 31 to both $\mathrm{Mn}$ deficiency and toxicity could be ascribed to higher levels of antioxidant enzyme activities and thus to lower oxidative stress.

The existence of a cell adaptation mechanism to excessive Mn availability $(200.0 \mu \mathrm{mol} \mathrm{L}-1$ $\mathrm{Mn}$ ), by increasing the size of chloroplasts as well as their number per cell area was observed in Santa Rosa and markedly in IAC-Foscarin 31 cultivars. Furthermore, according to the anatomical changes and timing of appearance of the symptoms of Mn deficiency and toxicity observed here, we believe there are various mechanisms that act together to maintain the biochemical processes and structural plant apparatuses, resulting in different degrees of tissue organization.

The IAC-Foscarin 31 showed the lowest $K_{m}$ and higher $V_{\max }$, which has increased the efficiency of absorption. The efficiency of absorption and use of Mn by soybean plants were higher in the cultivars IAC-31 Foscarin> IAC-15 $\geq$ Santa Rosa.

\section{References}

Arru, L.; Rognoni, S.; Baroncini, M.; Bonatti, P.M. \& Perata, P. (2004). Copper localization in Cannabis sativa L. grown in a cooper-rich solution. Euphytica, Vol.140, (33-38), ISSN 0014-2336.

Baldisserotto, C.; Ferroni, L.; Medici, V.; Pagnoni, A.; Pellizzari, M.; Fasulo, M.P.; Fagioli, F.; Bonora, A. \&Pancaldi, S. (2004). Specific intra-tissue responses to manganese in the floating lamina of Trapa natans L. Plant Biology, Vol.6, (578-589), ISSN 1435-8603.

Bidwell, S.D.; Woodrow, I.E.; Batianoff, G.N. \& Sommer-Knudsen, J. (2002). Hyperaccumulation of manganese in the rainforest tree Austromystus bidwillii (Myrtaceae) from Queensland, Australia. Functional Plant Biology, Vol.29, (899-905), ISSN 14454408.

Broadhurst, C.L.; Chaney, R.L.; Angle, J.S.; Maugel, T.K.; Erbe, E.F. \& Murphy, C.A. (2004). Simultaneous hyperaccumulation of nickel, manganese and calcium in Alyssum leaf trichomes. Environmental Science \& Technology, Vol.38, (5797-5802), ISSN 1520-5851.

Broadley, M.R.; White, P.J. (2005). Plant nutritional genomics. Blackwell Publishing: Oxford, UK.

Demirevska-Kepova, K.; Simova-Stoilova, L.; Stoyanova, Z.; Holzer, R. \& Feller, U. (2004). Biochemical changes in barley plants after excessive supply of cooper and manganese. Environmental and Experimental Botany, Vol.52, (253-266), ISSN: 00988472.

Di Toppi, L.S.; Musetti, R.; Vattuone, Z.; Pawlik-Skowronska, B.; Fossati, F.; Bertoli, L.; Badiani, M. \& Favali, M.A. (2005). Cadmium distribution and effects on ultrastructure and chlorophyll status in photobionts and mycobionts of Xathoria parietina. Microscopy Research and Technique, Vol.66, (229-238), ISSN (electronic) 1097-0029.

Doncheva, S.; Georgieva, K.; Vassileva, V.; Stoyanova, Z.; Popov, N. \& Ignatov, G. (2005). Effects of succinate on manganese toxicity in pea plants. eburnal of Plant Nutrition, Vol.28, (47-62), ISSN (electronic): 1532-4087.

Ducic, T. \& Polle, A. (2005). Transport and detoxification of manganese and copper in plants. Brazilian eburnal of Plant Physiology, Vol.17, (103-112), ISSN: 16770420. 
Epstein, E. \& Bloom, A.J. (2005). Mineral nutrition of plants: principles and perspectives. Sinauer: Sunderland, MA, USA.

Fageria, N.K. (2001). Adequate and toxic levels of copper and manganese in upland rice, common bean, corn, soybean and wheat grown on an oxisol. Communications in Soil Science and Plant Analysis, Vol.32, (1659-1676), ISSN: 1532-2416.

Fernando, D.R.; Bakkaus, E.J.; Perrier, N.; Baker, A.J.M.; Woodrow, I.E. Batianoff, G.N. \& Collins, R.N. (2006a). Manganese accumulation in the leaf mesophyll of four tree species: a PIXE/EDAX localization study. New Phytologist, Vol.171, (751-758), ISSN: 1469-8137.

Fernando, D.R.; Batianoff, G.N.; Baker, A.J.M. \& Woodrow, I.E. (2006b). In vivo localization of manganese in the hyperaccumulator Gossia bidwilli (Benth.) N. Snow \& Guymer (Myrtaceae) by cryo-SEM/EDAX. Plant, Cell \& Environment, Vol.29, (1012-1020), ISSN: 1365-3040.

Fitter, A. C. (1996). Characteristics and functions of root systems. In: Waisel, Y.; Eshel, A. \& Kafkafi, U., eds. Plant roots: The Ridden Half. 2. ed., p.1-20. New York: Marcel Dekker.

Foy, C.D.; Scott, B.J.; \& Fisher, J.A. (1988). Genetics differences in plant tolerance to manganese toxicity. In: Graham, R.D.; Hannam, R.J.; Uren, N.C., eds. Manganese in soils and plants. p.293-307. Kluwer Academic Publishers, Dordrecht, The Netherlands.

Führs, H.; Hartwig, M.; Molina, L.E.B.; Heintz, D.; Van Dorsselaer, A.; Braun, H.P. \& Horst, W.J. (2008). Early manganese-toxicity response in Vigna unguiculata L. - a proteomic and transcriptomic study. Proteomics, Vol.8, (149-159), ISSN: 1615-9861.

González, A. \& Lynch, J.P. (1999). Subcellular and tissue Mn compartmentalization in bean leaves under Mn toxicity. Australian eburnal of Plant Physiology, Vol.26, (811-822), ISSN: 0310-7841.

Graham, R.D. (1988). Genotypic differences in tolerance to manganese deficiency. In: Graham, R.D.; Hannam, R.J.; Uren, N.C., eds. Manganese in soils and plants. p.261276. Kluwer Academic Publishers, Dordrecht, The Netherlands.

Henriques, F.S. (2003). Gas exchange, chlorophyll $a$ fluorescence kinetics and lipid peroxidation of pecan leaves with varying manganese contents. Plant Science, Vol.165, (239-244), ISSN 0306-4484.

Henriques, F.S. (2004). Reduction in chloroplast number accounts for the decrease in the photosynthetic capacity of Mn-deficient pecan leaves. Plant Science, Vol.166, (10511055), ISSN 0306-4484.

Huber, D.M. \& Graham, R.D. (1999). The role of nutrition in crop resistance and tolerance to diseases. In: Rengel, Z., ed. Mineral nutrition of crops: fundamental mechanisms and implications. p.169-204. New York: Food Products Press,

Izaguirre-Mayoral, M.L. \& Sinclair, T.R. (2005). Soybean genotypic difference in growth, nutrient accumulation and ultrastructure in response to manganese and iron supply in solution culture. Annals of Botany, Vol.96, (149-158), ISSN 1095-8290.

Küpper, H.; Zhao, F.J. \& Mcgrath, S.P. (1999). Cellular compartmentation of zinc in leaves of the hyperaccumulator Thlaspi caerulescens. Plant Physiology, Vol.119, (305-311), ISSN 1532-2548. 
Johnson, C.M.; Stout, P.R.; Broyer, T.C. \& Carlton, A.B. (1957). Comparative chlorine requirements of different plants species. Plant and Soil, Vol.8, (337-353), ISSN: 15735036.

Jungk, A.O. (1996). Dynamics of nutrient movement at the soil-root interface. In: Waisel, Y.; Eshel, A.; Kafkafi, U. (Eds.) Plant roots: the ridden half. 2.ed. New York: Marcel Dekker, p.529-556.

Lavres Jr., J. (2007). Influência genotípica na absorção, utilização e na toxidez de manganês na soja. Piracicaba: University of Sao Paulo, $88 \mathrm{p}$. PhD Thesis.

Lavres Jr, J.; Malavolta, E.; Nogueira, N.L.; Moraes, M.F.; Reis, A.R.; Rossi, M.L. \& Cabral, C.P. (2009). Changes in anatomy and root cell ultrastructure of soybean genotypes under manganese stress. Brazilian eburnal of Soil Science, Vol.33, (395-403), ISSN 1806-9657.

Lavres Jr, J.; Reis, A.R.; Rossi, M.L.; Cabral, C.P.; Nogueira, N.L. \& Malavolta, E. (2010). Changes in the ultrastructure of three soybean cultivars in response to manganese supply in solution culture. Scientia Agricola, Vol.67, (287-294), ISSN 0103-9016.

Lidon, F.C. (2002). Rice plant structural changes by addition of excess manganese. eburnal of Plant Nutrition, Vol.25, (287-296), ISSN (electronic): 1532-4087.

Lima, D.V.; Kliemann, H.J.; Moraes, M.F. \& Leandro, W.M. (2004). Effect of liming and manganese rates on soybean mineral nutrition in the region of Rio Verde, State of Goias, Brazil. Tropical Agriculture Research, 34: 61-69.

Malavolta, E.; Vitti, G.C. \& Oliveira, S.A. (1997). Avaliação do estado nutricional das plantas: princípios e aplicações. 2.ed. Piracicaba: POTAFOS, 319p.

Malavolta, E. (2006). Handbook of plant mineral nutrition. Editora Agronômica Ceres: São Paulo, Brazil. (In Portuguese).

Morita, A.; Yokota, H.; Ishka, M.R. \& Ghanati, F. (2006). Changes in peroxidase activity and lignin content of cultured tea cells in response to excess manganese. Soil Science and Plant Nutrition, Vol.52, (26-31), ISSN 0038-0768.

Mcquattie, C. J. \& Schier, G.A. (2000). Response of sugar maple (Acer saccharum) seedlings to manganese. Canadian eburnal of Forest Research, Vol.30, (456-467), ISSN: 1208-6037.

Nye, P.H. \& Tinker, P.B. (1977). The uptake properties of the root system in solution. In: Nye, P.H.; Tinker, P.B. (Eds.) Solute movement in the soil-root system. 1.ed. Oxford: Blackwell Scientific Publications, p.92-126.

Papadakis, I.E.; Bosabalidis, A.M.; Sotiropoulos, T.E. \& Therios, I.N. (2007a). Leaf anatomy and chloroplast ultrastructure of Mn-deficient orange plants. Acta Physiologia Plantarum, Vol.29, (297-301), ISSN: 1861-1664.

Papadakis, I.E.; Giannakoula, A.; Antonopoulou, C.P.; Moustakas, M.; Avramaki, E. \& Therios, I.N. (2007b). Photosystem II activity of Citrus volkameriana (L.) leaves as affected by Mn nutrition and irradiance. Photosynthetica, Vol.45, (208-213), ISSN: 1573-9058.

Papadakis, I.E.; Giannakoula, A.; Therios, I.N.; Bosabalidis, A.M.; Moustakas, M. \& Nastou, A. (2007c). Mn-induced changes in leaf structure and chloroplast ultrastructure of Citrus volkamericana (L.) plants. eburnal of Plant Physiology, Vol.164, (100-103), ISSN 0176-1617.

Pittman, J.K. (2005). Managing the manganese: molecular mechanisms of manganese transport and homeostasis. New Phytologist, Vol.167, (733-742), ISSN: 1469-8137. 
Reid, R.J. (1999). Kinetics of nutrient uptake by plant cells. In: Rengel, Z. (Ed.) Mineral nutrition of crops: fundamental mechanisms and implications. 1.ed. New York: Food Products Press, p.41-66.

Rengel, Z. (1999). Physiological mechanisms underlying differential nutrient efficiency of crop genotypes. In: Rengel, Z. Mineral nutrition of crops: fundamental mechanisms and implications. p.227-265. New York: Food Products Press.

Rosolem, C.A.; Sacramento, L.V.S \& Oliveira, D.M.T. (2005). Kinetics of zinc uptake and anatomy of roots and leaves of coffee trees as affected by zinc nutrition. eburnal of Plant Nutrition, Vol.28, (2101-2112), ISSN (electronic): 1532-4087.

Santandrea, G. Schiff, S. \& Bennici, A. (1998a). Effects of manganese on Nicotiana species cultivated in vitro and characterization of regenerated Mn-tolerant tobacco plants. Plant Science, Vol.132, (71-82), ISSN 0306-4484.

Santandrea, G. Tani, C. \& Bennici, A. (1998b). Cytological and ultrastructural response of Nicotiana tabacum L. roots to manganese stress. Plant Biosystems, Vol.132, (197-206), ISSN (electronic): 1724-5575.

Sas Institute. SAS/STAT. (1996). User's guide, version 6.11. Cary, North Carolina, USA.

Tanaka, R.T.; Mascarenhas, H.A.A.; Bulisani, E.A. (1992). Manganese deficiency in soybean due to excessive liming. Brazilian eburnal of Agricultural Research, Vol.27, (247-250), ISSN 1678-3921.

Thompson, I.A. \& Huber, D.M. (2007). Manganese and plant disease. In: Datnoff, L.E.; Elmer, W.H. \& Huber, D.M., eds. Mineral nutrition and plant disease. p.139-153. Saint Paul: APS Press.

Weiland, R.T.; Noble, R.D. \& Crang, R.E. (1975). Photosynthetic and chloroplast ultrastructural consequences of manganese deficiency in soybean. American eburnal of Botany, Vol.62, (501-508), ISSN 1537-2197.

Yan, S.L.; Tsay, C.C. \& Chen, Y.R. (2000). Isolation and characterization of phytochelatin synthase in rice seedlings. Proceedings of the National Science Council, Republic of China. Part B, Vol.24, (202-207), ISSN: 0255-6596. 


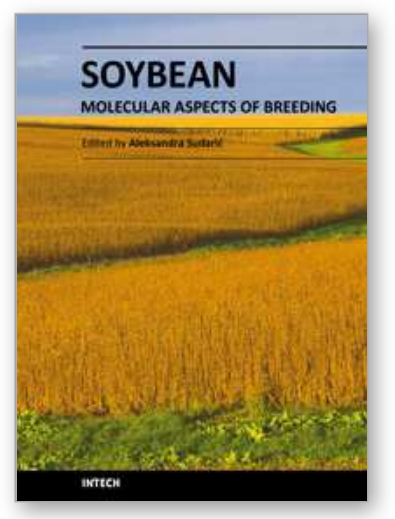

\author{
Soybean - Molecular Aspects of Breeding \\ Edited by Dr. Aleksandra Sudaric
}

ISBN 978-953-307-240-1

Hard cover, 514 pages

Publisher InTech

Published online 11, April, 2011

Published in print edition April, 2011

The book Soybean: Molecular Aspects of Breeding focuses on recent progress in our understanding of the genetics and molecular biology of soybean and provides a broad review of the subject, from genome diversity to transformation and integration of desired genes using current technologies. This book is divided into four parts (Molecular Biology and Biotechnology, Breeding for Abiotic Stress, Breeding for Biotic Stress, Recent Technology) and contains 22 chapters.

\title{
How to reference
}

In order to correctly reference this scholarly work, feel free to copy and paste the following:

Andre Rodrigues dos Reis and Jose Lavres Junior (2011). Genotypic Influence on the Absorption, Use and Toxicity of Manganese by Soybean, Soybean - Molecular Aspects of Breeding, Dr. Aleksandra Sudaric (Ed.), ISBN: 978-953-307-240-1, InTech, Available from: http://www.intechopen.com/books/soybean-molecularaspects-of-breeding/genotypic-influence-on-the-absorption-use-and-toxicity-of-manganese-by-soybean

\section{INTECH}

open science | open minds

\author{
InTech Europe \\ University Campus STeP Ri \\ Slavka Krautzeka 83/A \\ 51000 Rijeka, Croatia \\ Phone: +385 (51) 770447 \\ Fax: +385 (51) 686166 \\ www.intechopen.com
}

\author{
InTech China \\ Unit 405, Office Block, Hotel Equatorial Shanghai \\ No.65, Yan An Road (West), Shanghai, 200040, China \\ 中国上海市延安西路65号上海国际贵都大饭店办公楼 405 单元 \\ Phone: +86-21-62489820 \\ Fax: $+86-21-62489821$
}


(C) 2011 The Author(s). Licensee IntechOpen. This chapter is distributed under the terms of the Creative Commons Attribution-NonCommercialShareAlike-3.0 License, which permits use, distribution and reproduction for non-commercial purposes, provided the original is properly cited and derivative works building on this content are distributed under the same license. 